Zorica P. Hadžić*

Filozofski fakultet

Univerzitet u Novom Sadu
UDK 821.163.41.09"1918/1941" Kašanin M. 821.163.41.09"1918/1941" Kovačević B.

DOI: 10.19090/gff.2019.2.163-175

Originalni naučni rad

\title{
MILAN KAŠANIN I BOŽIDAR KOVAČEVIĆ: DVA LICA JEDNE KRITIKE $^{* *}$
}

U radu se na primeru recepcije pripovedačke proze Milana Kašanina istražuje koliko promena istorijskih i političkih prilika može da utiče na poziciju i prijem u kritici jednog pisca. Pripovedna proza Milana Kašanina štampana između dva rata do naših dana ostala je nedovoljno proučena, a sporadične ocene kritike odlikuje upadljiva neusaglašenost u iznošenju vrednosnih sudova. U međuratnom periodu Kašanin je objavio dve pripovedačke zbirke, a povodom njihovog objavljivanja oglasio se i Božidar Kovačević. Pored dveju štampanih kritika, sačuvan je u rukopisu i jedan Kovačevićev referat na nikad objavljenu zbirku Kašaninovih pripovedaka, napisan neposredno po okončanju Drugog svetskog rata. Ova poslednja kritičarska metamorfoza Božidara Kovačevića pokazaće kako se svojevremeno štampane pozitivne ocene mogu izmeniti i poništiti u svetlu novih političkih okolnosti.

Ključne reči: recepcija, književna kritika, međuratna književnost, recenzija, rukopis.

U jednoj kritici Milana Kašanina, objavljenoj u Letopisu Matice srpske 1928. godine, naići ćemo na razmišljanje o tome šta sve određuje poziciju i književni uspeh jednog pisca. ${ }^{1}$ Kašanin, povodom pesama Todora Manojlovića, tačno i precizno rezonuje:

Za uspeh u književnosti traži se isto toliko umešnosti i sreće koliko i za uspeh u životu. Treba biti krajnje naivan pa misliti da su vrednost i značaj jednog pesnika tačno onakvi i onoliki kako to stoji u kritikama i istorijama književnosti. Jedna knjiga vredi samo onoliko koliko joj vrednosti daje čitalac. Nema tačnih ni netačnih kritika, nego samo kritika s kojima se čitalac više ili manje slaže. Nikad ne treba ceniti jednog pisca po onome što o njemu pišu kritičari. Glas jednom

\footnotetext{
*zorica_hadzic@ff.uns.ac.rs

** Rad je nastao kao deo naučnog projekta 178005, čiji je rukovodilac prof. dr Svetlana Tomin, a koji finansira Ministarstvo prosvete, nauke i tehnološkog razvoja Republike Srbije.

${ }^{1}$ Kašanin je ovu kritiku preštampao u knjizi Pronađene stvari 1961. godine.
} 
pesniku određuju i tako bedne stvari kao što su lične veze, trenutak ulaska u književnost i književne predrasude i simpatije. O svakoj knjizi i svakom piscu čitalac treba sam da stvori svoj sud i mišljenje (Kašanin, 1928: 282-283).

U vreme kada piše ove redove, Kašanin je živo prisutan u srpskoj književnosti: objavljuje kritike i pripovetke, piše romane. Njegova afirmacija, započeta još u gimnazijskim danima, nastavila se kroz pisanje književne i likovne kritike. Za vreme Prvog svetskog rata štampa zapažene priloge u Obzoru, Savremeniku i Književnom Jugu. Već u to vreme on je uveliko zaokupljen razmišljanjem o sopstvenom književnom delu. Po okončanju Prvog svetskog rata upisuje studije istorije umetnosti i uporedne književnosti na Sorboni i kao francuski đak, uz pomoć i podršku Isidore Sekulić, štampa prvu pripovetku. Pripovetka „Mrav”, objavljena u Srpskom književnom glasniku 1921. godine, bila je propraćena pohvalnim pisanjem tadašnjeg urednika, Vojislava Jovanovića Maramboa, o mladom piscu kao velikoj nadi srpske književnosti - to je bio doček kakvim bi retko koji početnik mogao da se pohvali. Nema sumnje da je ovako najavljen ulazak Milana Kašanina u književnost morao da izazove pažnju savremenika, sračunato budeći njihovu radoznalost, ali i podozrivost. ${ }^{2}$ Usledile su, nekoliko godina kasnije, i dve zbirke pripovedaka: Jutrenja i bdenja (1925) i Zaljubljenici (1928). Naporedo sa umetničkom prozom Kašanin nastavlja da piše književnu i likovnu kritiku. Aktivno učestvujući u književnom životu, imao je prilike da se uveri u kojoj meri vanliterarne okolnosti mogu da kroje kapu piscu i odrede njegov uspeh. Jedino što tada nije mogao ni da nasluti jeste to da će i sudbinu njegovog međuratnog opusa, na neki način, determinisati istorijske i političke prilike posle Drugog rata. Nijanse između (ne)priznavanja nečijeg književnog stvaranja i, naizgled, afirmativnih kritika istog tog dela pokazaćemo na primeru kritike Božidara Kovačevića. Naš fokus će biti usmeren na to kako je književnik i kritičar Božidar Kovačević čitao pripovetke Milana Kašanina pre i posle Drugog svetskog rata.

Sedam godina mlađi od Kašanina, i Božidar Kovačević je rano zakoračio u književnost: bio je zapažen kao darovit gimnazijalac, aktivan u književnim družinama. Radoznao i zainteresovan, ogledao se u stihu, prozi i kritici. Dakle, i Kašanin i Kovačević u međuratnom periodu istovremeno su pisali kritiku i

${ }^{2}$ Ima primera da je među predstavnicima starije generacije književnih radnika „Mrav” izazvao nerazumevanje i podsmeh. Milan Savić je povodom ove Kašaninove pripovetke pisao Pavlu Popoviću: „Ostajem pri svom mišljenju što se 'Mrava' tiče a smejao sam se vašoj opasci o 'stisku ruke'. Ja tu novelu dotle nisam ni čitao" (Arhiv SANU, inv. br. 14492/152-5, pisano ćirilicom). 
originalna umetnička dela, prevodili. U kritičkom praćenju raznorodne i bogate književne produkcije između dva svetska rata, njih dvojica se nisu mimoišli Kašanin je pisao o Kovačeviću, a Kovačević o Kašaninu. Dakle, književna kritika koju su obojica objavljivali između dva rata jasno potvrđuje da su veze između njih postojale $\mathrm{i}$ da su se čitali, a kao još interesantnije ukazuje se razlikovanje u nijansama vrednosnih sudova, što ćemo i pokazati držeći se hronologije.

Najpre je interesovanje za književno delo mladog Božidara Kovačevića pokazao Milan Kašanin. U Letopisu Matice srpske 1925. godine, u rubrici „Knjige i listovi", objavio je nekoliko rečenica posvećenih Kovačevićevoj trećoj pesničkoj zbirci, Orač tišine (Kašanin, 1925: 155). U tom periodu Kašanin je marljiv saradnik Letopisa i pomoćnik iz senke glavnog urednika, Marka Maletina. Beleška o novoj knjizi Božidara Kovačevića bila je efektna, nepretenciozna i - što je važno - u svemu afirmativna. U ovom osvrtu mladi pesnik je čitaocima Letopisa predstavljen kao ,jedan od najdarovitijih i najinteligentnijih naših najmlađih književnika” (155), uspešan podjednako u stihu i prozi. Među koricama Kovačevićeve zbirke kritičar je prepoznao iskrenost $\mathrm{u}$ osećanju, jednostavnost $\mathrm{u}$ izlaganju, harmoniju između tradicije i modernosti i ,nekoliko pesama i još više lepih stihova” (155).

Već naredne godine, uz ponovno izdvajanje Božidara Kovačevića kao „sasvim mladog, ali vrlo vrednog književnog radnika” (Kašanin, 1926: 316), samo ovoga puta u nešto smirenijem tonu, bez egzaltacije i superlativa (najdarovitiji, najinteligentniji) izrečenih $\mathrm{u}$ prethodnom osvrtu, Kašanin je u martovskom broju Letopisa objavio belešku o izboru iz poezije Božidara Kovačevića. Ukazao je na raznovrsnost u pevanju mladog pesnika što ,traži nove puteve i pokušava da stvara u vrlo raznim pravcima" (316). I u ovoj knjizi, kao i u prethodnoj, kritičar je pronašao ,nekoliko odličnih pesama i još više odličnih stihova” (316). Uostalom, nije mu bila namera da svoj kritički sud razradi i utemelji primerima, iako je iz ove beleške sasvim jasna njegova ocena stihova. Drugim rečima, ovaj osvrt Kašanin je i napisao jer je smatrao da bi pojava Kovačevićeve zbirke morala da se zabeleži u Letopisu. ${ }^{3}$

${ }^{3}$ Ovaj podatak nam je poznat zahvaljujući sačuvanoj prepisci Milana Kašanina i Marka Maletina. U pismu od 4. marta 1926. godine Kašanin obaveštava urednika Letopisa, Maletina: „I pored najbolje volje i truda nisam mogao nabaviti prikaze o Sibu i Kovačeviću za ovaj, martovski broj. Profesionalnih kritičara nema, a pisci se nerado toga prihvataju. Zato sam ti i poslao beleške, - da knjige ne bi prošle nezabeležene od Letopisa. Sad, kad imaš prikaz o Kovačeviću od N. Mirkovića, - koji, kao što znaš ne živi stalno u Beogradu, pa ga nisam mogao ni umoliti za taj prikaz, - ostaje jedino da ti se nađe prikaz o Sibu. Zasad 
Posle ovih dveju afirmativnih Kašaninovih beležaka, oglasio se iste, 1926. godine Božidar Kovačević. U martovskom broju kratkovekog časopisa Reč i slika, u okviru rubrike „Književna hronika”, objavio je prikaz tri knjige „značajne i po njihovim piscima i po sadržini” (Kovačević, 1926: 94-97). Kovačević je tom prilikom ukazao na pripovetke Veljka Petrovića u izdanju Srpske književne zadruge, knjigu Borovi $i$ masline Siba Miličića i Kašaninovu prvu zbirku pripovedaka, Jutrenja i bdenja. Autora zbirke Jutrenja i bdenja predstavio je kao novog pripovedača, podsećajući čitaoce na njegove kritike iz Književnog Juga. Iščitavajući Kašaninove pripovetke, uočio je da je pisac uspešno vratio u srpsku književnost jedan ,zaboravljen kraj, Baranju, iz koje vuče svoju živahnu krv, nešto umirenu i umerenu uticajem moderne francuske pripovetke" (97), u čijem je prikazivanju vešto uspeo da izbegne izvesne „lokalnosti” (97). Kovačević je istakao i pohvalio „lep humor” što daje pripovetkama „,naročitu draž kao javanske mirođije malajskim jelima" (97). Taj humor, pored drugih vrlina, kritičar je prepoznao u pripovetkama „Mrav” i „Nije to ono”. Kao najuspelije izdvojio je tri priče sa kraja knjige („Izmirenje”, „Na mesečini”, „Nemoć”), od kojih po vrednosti prednjači „Nemoć”, jer po originalnosti fabule i umetničke obrade spada u ,najlepše, najsuptilnije pripovetke napisane posle Velikog Rata" (97). Njoj Kovačević vidi mesto u svakoj našoj antologiji, sugerišući piscu da nastavi da piše pripovetke $u$ „istom žanru”. Prikaz Božidara Kovačevića povodom prve zbirke pripovedaka ovog baranjskog Srbina jeste, u svojoj suštini, afirmativan, a pripovetka „Nemoć” zaista se izdvaja kao jedna od najboljih u zbirci.

Međutim, njih dvojica se nisu samo hvalili. Nakon što je Milan Kašanin napisao negativnu ocenu njegove Antologije ljubavne lirike, Kovačević je još jače uzvratio. Usledila su, dakle, dva negativna prikaza.

Prvi je napisao Kašanin već naredne, 1927. godine u Letopisu Matice srpske. Ovoga puta tema je Kovačevićev antologičarski rad (Kašanin, 1927: 149150). Kovačević je objavio izbor iz ljubavne lirike imajući na umu pesme, a ne pesnike, kako je zapisao u predgovoru. U prikazu pod naslovom „Još jedna antologija" - već po naslovu se može naslutiti stav kritičara - Kašanin podseća da se posle Antologije novije srpske lirike Bogdana Popovića u srpskoj književnosti pojavio niz manje značajnih antologijskih izbora. Ali kada se već objavljuje još jedna antologija, Kašanin je izričan u stavu da je veoma važno kako je zamišljena i kakav je izbor učinjen. Upravo je zbog manjkavosti tih dvaju, po njegovom

mi je obećao B. Kovačević da o njoj piše, a raspitaću se i na drugim stranama, pa će se svakako neko naći” (ROMS, inv. br. 10. 735; pisano ćirilicom). 
mišljenju, presudnih elemenata Kašanin i zamerio antologičaru. U trenutku kada Božidar Kovačević objavljuje Antologiju ljubavne lirike, Kašanin smatra da bi svrsishodnije za srpsku književnost bilo da je sačinio antologiju posleratnog pesništva ili pripovetke. ${ }^{4}$ Glavne i suštinske zamerke tek su usledile. Kašanin nema reči hvale za izbor Božidara Kovačevića, koji se nije zadržao samo na stihovima srpskih, već je uneo i hrvatske i dubrovačke pesnike, dodajući im još i određen broj narodnih pesama. Imao je primedbe i na organizaciju pesama unutar antologije „napraviti ovakvu jednu kakofoničnu i haotičnu 'orkestraciju', to je direktno namet estetičkog smisla i osećanja" (150). Oštre kritike su upućene i izboru Božidara Kovačevića, a ticale su se i broja pesama kojima su pojedini pesnici predstavljeni (Rakić i Vidrić po tri pesme, Domjanić i Krklec dve, izostale su pesme Kranjčevićevih, Milete Jakšića i Rastka Petrovića itd.). U svetlu činjenice da je sam antologičar zastupljen sa čak 11 (!) pesama, Kašaninove primedbe ukazuju se kao opravdane. Primer Božidara Kovačevića i njegovog neselektivnog izbora, naročito kada je reč o sopstvenim stihovima, nije usamljen u srpskoj književnosti. No ovaj krajnje neobičan odnos antologičara prema svojim stihovima Kašanin pacifikuje $i$, donekle, pravda mladošću: „To je možda malo mnogo i od jednog tako mladog i ambicioznog čoveka kao što je g. Božidar Kovačević” (150).

Iako savremeni kritičari zameraju Kašaninu što je između dva rata pisao nenametljivu kritiku, držao se sa strane i uzdržano iznosio kritičke ocene (Palavestra, 2008: 441), nećemo se saglasiti sa njihovom selektivnom ocenom, jer Kašaninova kritika nije do te mere pojednostavljena da bismo o njoj sudili držeći se, uglavnom, piščevog posleratnog izbora iz kritika objavljenog u knjizi Pronađene stvari (1961). Ovako striktan sud o umerenosti Milana Kašanina kao kritičara ispostavlja se kao uopšten i neodrživ, jer ne podrazumeva i Kašaninove negativne kritike, beleške, osvrte i sl. Ako ništa drugo, kritički prikaz Antologije ljubavne lirike u izboru Božidara Kovačevića pokazuje da Kašanin nije bio od onog soja umerenih književnih kritičara, kakvim ga najčešće predstavljaju.

Nepune dve godine nakon negativne kritike Antologije ljubavne lirike usledilo je pisanje Božidara Kovačevića o drugoj pripovedačkoj zbirci Milana Kašanina, Zaljubljenici, u Pravdi 5. marta 1929. godine (Kovačević, 1929: 5). Nakon konstatacije da su se kritičari listom obrušili na novu Kašaninovu knjigu, ujedinjeni u oceni da je slabija od prethodne, Kovačević započinje u umerenom

\footnotetext{
${ }^{4}$ Božidar Kovačević je prethodno sastavio Antologiju romantičarske pripovetke, 1924. godine.
} 
tonu i, naizgled, naklonjeno piscu. ${ }^{5}$ Njegova ocena je da knjiga nije ni bolja ni gora od prethodne - obe imaju više mana nego vrlina, ali smatra da je to česta karakteristika prvih knjiga i najboljih pisaca. (Uzgred, u prikazu prve knjige Kašaninovih pripovedaka Kovačević nije pominjao mane, ali jeste vrline.) Nakon što će, u brzim potezima, rezimirati i potvrditi svoju ocenu vezanu za kritiku prethodne zbirke, Jutrenja $i$ bdenja, još jednom odajući priznanje Kašaninovom dobroćudnom humoru i prijatnom stilu, kritičar će vrlo brzo otvoriti karte ispisujući dosledno negativno intoniranu kritiku. Jer kako bi drugačije mogla da se shvati kritika u kojoj stoji da je Kašanin pisac ,sa više dobre volje nego talenta, sa više vrednoće i ambicije nego stvaralačkog daha, intelektualno dosta naivan, a slab psiholog” (5)? Zatim će mu smetati to što u pripovetkama nedostaje „tragično osećanje života” (5), koje Kašanin uzalud pokušava da nadoknadi ,gorkim lirizmom Crnjanskoga” (5). U nastavku, Kovačević ukazuje na pripovetke koje se baziraju na banalnim motivima i nedovoljno dobroj umetničkoj obradi, a junaci njegovih priča tako su papirnati da više nalikuju voštanim lutkama nego živim ljudima. Paradoks je u tome što Kovačević ilustruje slabosti Kašaninove proze na primeru pripovedaka „Preobraženje” i „Ženih”, dok ih pojedini savremeni kritičari (Predrag Protić, Slavko Gordić) svrstavaju među uspelije pripovetke u piščevom opusu. Za Božidara Kovačevića najuspelija pripovetka ove zbirke jeste „Grešnici”. Nakon čitanja prikaza teško je, dakle, poverovati da je Kovačević imao nameru da odbrani pripovedača od napada kritike i da je želeo da napiše neutralnu i umerenu kritiku. Otvoreno pitanje može da ostane o tome da li je Kovačevićevu kritiku, makar jednim delom, diktirala sujeta povređenog antologičara.

U svakom slučaju, tri Kašaninova osvrta na Kovačevićevo literarno delo i dva prikaza Božidara Kovačevića posvećena pripovetkama Milana Kašanina jesu tekstovi posle kojih se nisu više oglašavali ocenjujući rad jedan drugom; sujete su bile dovoljno uzdrmane, a putevi im se nisu bitno ukrštali. ${ }^{6}$

U međuratnom periodu Kašanin je, pored dveju pomenutih pripovedačkih zbirki, štampao i dva romana: Trokošuljnik i Pijana zemlja. Međutim, izvesna pauza u njegovom književnom radu nastaje kada je postavljen na mesto direktora Muzeja kneza Pavla. Formiranje modernog muzeja, brojne izložbe, nabavka slika,

\footnotetext{
${ }^{5}$ Među kritičarima koji su se obrušili na Kašaninovu zbirku prednjačio je Velibor Gligorić.

${ }^{6}$ Od 1935. godine obojica su se našli na istom poslu - bili su članovi uređivačkog odbora Srpskog književnog glasnika, kada je glavni urednik bio Milan Predić. Od 1939. Božidar Kovačević je uređivao Srpski književni glasnik.
} 
uređivanje Umetničkog pregleda i druge obaveze vezane za vođenje ove kulturne ustanove ometale su ga u intenzivnom pisanju proze. S druge strane, bliskost i saradnja sa knezom Pavlom uticale su svakako na promenu društvene pozicije Milana Kašanina. Međutim, za vreme Drugog svetskog rata i u posleratnim godinama političke prilike su se promenile. Kašanin je ostao u Beogradu, gde je proveo okupaciju radeći svakodnevno u Muzeju kao direktor. Da nesreća nikada ne ide sama pokazalo se i kada su mu, za vreme uličnih borbi, oktobra 1944. godine, nemački vojnici zapalili stan. Po okončanju rata, Kašaninova saradnja sa knezom Pavlom i činjenica da je štampao dve knjige tokom okupacije bile su dovoljne da bude penzionisan i prokažen. ${ }^{7}$ Gotovo preko noći ostao je bez posla i bez doma, odgurnut na ivicu egzistencije. U tekstu ,Za mač i za pero!’, štampanom u Borbi 1. decembra 1944, osioni Radovan Zogović nazvao ga je književnikom-kvislingom, a dodeljena etiketa u stopu će ga pratiti i za njom će se, po potrebi, posezati. ${ }^{8}$ Bez novčanih primanja, gurnut u nemilost, Milan Kašanin je pokušavao da radi ono što je najbolje znao - da piše - kako bi obezbedio egzistenciju svojoj porodici. Međutim, njegova skrajnutost uslovila je da to pisanje bude isključivo za ladicu. Nije bilo načina da u uzavreloj političkoj atmosferi i jednoumlju njegovo delo dođe do čitalačke publike. U novim prilikama, kada su se svi čuvali saradnje sa njim, Kašanin je prevodio. Kao što je anonimno prevodio, tako je, takođe nepotpisan, sarađivao u Politikinoj rubrici „Da li znate?”. Nije još uvek dovoljno istraženo kojim je sve putevima Milan Kašanin pokušavao da se vrati u književni život. U prvim godinama posle Drugog svetskog rata za njega su bila zatvorena gotovo sva vrata.

${ }^{7}$ Reč je o knjigama Milana Kašanina Dva veka srpskog slikarstva (1942) i Umetnost $i$ umetnici (1943).

8 „Zatim je došla fašistička okupacija - tri i po godine robovanja njemačkim i italijanskim varvarima i njihovim slugama”, grmeo je Zogović, ,robovanja Jozefu Gebelsu i Veliboru Joniću, Hansu Jostu, koji se 'kad čuje reč kultura masa za revolver', i Velmaru Jankoviću, koga su njemački okupatori proglasili srpskim književnikom, [...] i kvisling-književnicima Svetislavu Stefanoviću, Todoru Manojloviću, Jeji Iliću, Momčilu Miloševiću, Milanu Kašaninu, B. L. Lazareviću i Veselinu Filipoviću-Brezancu, radio-generalu Ditmaru i gestapo-žurnalisti Mići Dimitrijeviću, marlen-muzičaru Kurtu Listu i 'zbor'-ovođi Svetomiru Nastasijeviću” (Zogović, 1947: 111).

Kada je Milan Kašanin, mnogo godina kasnije, predložen za člana Srpske akademije nauka, Vasko Popa se usprotivio, zato što je Kašanin sarađivao sa okupatorom. 
Nešto drugačija bila je ratna i poratna pozicija Božidara Kovačevića. Nakon odbijanja da svoj potpis stavi na zloglasni „Apel srpskom narodu” 1941. godine, otpremljen je u logor. S druge strane, Milan Kašanin, ratni direktor Muzeja i otac četvoro dece, potpisao je ovaj apel. O potpisivanju „Apela” Kašanin se nije kasnije izjašnjavao, kao što se, uostalom, ni u razgovorima vođenim sa Božidarom Kovačevićem nakon Drugog svetskog rata ne može pronaći podatak da je jedno vreme bio vaspitač prestolonaslednika Aleksandra II Karađorđevića. ${ }^{9}$ I jedan i drugi svoje rodoljublje manifestovali su onako kako su najbolje mogli i znali. Kašaninova misija bila je u tome da sačuva dragocenosti pohranjene u Muzeju kneza Pavla, među kojima i Miroslavljevo jevanđelje i zastave srpskih pukova, u čemu je uspeo. Kovačević je svoje rodoljublje pokazao hrabrim odbijanjem stavljanja potpisa na „Apel”. Ni Kovačeviću poratne prilike nisu uvek bile naklonjene; mesto urednika Naše književnosti izgubio je ,pod pritiskom partijskog agitpropa, samo zato što u bibliografiji o Svetozaru Markoviću nije precrtao ime tada ozloglašenog Slobodana Jovanovića" (Palavestra, 2008: 440).

Bilo kako bilo, teške posleratne godine udesile su još jedan „susret” starih znanaca - pripovedača Milana Kašanina i njegovog kritičara. U periodu od proleća 1947, pa do kraja 1955. godine, Božidar Kovačević je bio član književnog saveta Izdavačkog preduzeća „Prosveta”. Zadatak mu je bio da piše referate na pristigle rukopise i odlučuje da li će knjige biti objavljene ili neće. Ta dužnost poverena Kovačeviću nenadano otkriva još jedan pokušaj Milana Kašanina da se vrati u srpsku književnost. Naime, ostalo je nepoznato da je u prvim posleratnim godinama Milan Kašanin pokušao da objavi zbirku pripovedaka. Zajedno sa ostalim referatima koje je u tom periodu pisao, Kovačević je sačuvao i referat na ovu knjigu pripovedaka Milana Kašanina. ${ }^{10}$ Referat nije datiran, i kao najpreciznije određenje za sada se može uzeti to što na jednom mestu Kovačević kaže da Kašanin dugo nije pisao pripovetke i da „od oslobođenja nije učestvovao u književnom životu” - što upućuje na to da je napisan u periodu od 1947. do 1953. godine. Već 1953. Kašanin se vratio u književnost objavivši esej „Između orla i vuka” u beogradskoj Književnosti.

${ }^{9}$ Razgovore sa Božidarom Kovačevićem, objavljene i neobjavljene, sakupio je i priredio Staniša Vojinović.

${ }^{10}$ Referati Božidara Kovačevića čuvaju se u Arhivu SANU. Referat o Kašaninovoj knjizi kucan je mašinom, ćiriličnim pismom, i nalazi se pod signaturom 13133/10. 
Milan Kašanin je sakupio pet pripovedaka: „Mrav”, „Udovica”, „Braća pravoslavna”, „Na pijaci” i „Seljaci”, a knjizi je dao naslov po jednoj od pripovedaka iz izbora - Braća pravoslavna. ${ }^{11}$ Rukopis je ponudio za štampu Izdavačkom preduzeću „Prosveta” i on je došao na sto Božidara Kovačevića. Imajući u vidu tadašnje političke prilike i položaj Milana Kašanina u njima, pre nego što se okrenemo Kovačevićevoj oceni ponuđene knjige, moramo se zaustaviti da registrujemo pripovedačevu, katkad teško razumljivu, hrabrost. Ko bi, uostalom, u to vreme mogao i da zamisli u izlozima i na policama knjižara knjigu pod naslovom Braća pravoslavna, a iznad naslova ime pisca - Milan Kašanin?! No teško bismo poverovali da je Kašanin, ophrvan egzistencijalnim problemima, želeo na taj način da provocira, iako su pojedini istraživači videli čistu provokaciju, prst u oko tadašnjem režimu, u eseju „Između orla i vuka”.

Nije teško pretpostaviti zašto ova knjiga nikada nije objavljena. Nije bilo prepreka ni formalne prirode, jer je dobila negativnu recenziju. Kovačević je referat započeo Kašaninovim ulaskom u književnost i prisećanjem da je svojevremeno čitao neke od pripovedaka iz ponuđene zbirke. Nakon toga usledilo je čuđenje pisca referata: „Možete zamisliti moje iznenađenje kad sam, pročitavši te tako pohvaljene priče, video da se moj sadašnji utisak ne slaže s onim od pre trideset godina, ni mojim ni urednikovim. Ne čini mi se samo da nisu onako dobre, kako sam ih nekada smatrao, nego mi se baš ne sviđaju". Nešto kasnije, recenzent se ponovo čudio: „Našao sam se, dakle, u velikom čudu. Ugledan pisac [...] čovek koga lično volim i cenim, pa sad odjednom ne dopadaju mi se njegove pripovetke! Pročitao sam ih još jednom. Isti utisak: ne sviđa mi se, i kvit!" Kako bi ovaj referat izgledao vrlo površno i neozbiljno kad bi se sastojao samo od iščuđavanja i neutemeljenih izjava (baš mi se ne sviđaju; ne sviđa mi se, i kvit), Kovačević je nabrojao i slabosti ovog rukopisa: ironija je plitka, naivna i nekako pubertetska, a stil nategnut i neuverljiv. Lako je primetiti da se ova posleratna Kovačevićeva opaska o stilu Milana Kašanina kosi sa pohvalama piščevom stilu iskazanim u dvema prethodnim kritikama. Kada već poredimo kritičke ocene, recimo i to da u ovoj recenziji Kovačević ne pominje Kašaninov humor, koji je takođe bio istaknut u dvema prethodnim kritikama. Dve od ponuđenih pripovedaka („Udovica” i „Na pijaci”) više su feljtoni i dosetke, pripovetka „Mrav”, izdvojena u prvoj kritici, sada je neubedljiva, kao i „Seljaci”, a najduža pripovetka, „Braća pravoslavna”, neuverljiva

\footnotetext{
${ }^{11}$ Rukopis Kašaninove knjige nije sačuvan, te se ne zna da li je pisac intervenisao u tekstu pripovedaka prilikom spremanja knjige.
} 
je, loše komponovana i ne ubeđuje ga da je Kašanin prilikom posete brojnim manastirima „mogao naći ono što je opisao u ovoj pripoveci”.

Na kraju ovog negativnog referata Kovačević će se, izbegavajući da uđe u analizu pomenutih umetničkih i psiholoških nedostataka, pokolebati zbog strogog suda prema pripovedaču. „Predlažem da se jedna zbirka njegovih pripovedaka svakako objavi. Samo, trebalo bi odlučiti da li ova, ili jedan izbor iz njegovih zbirki i pripovedaka zaostalih po listovima. Možda bi Senatu bilo lakše da se odluči posle još jednog referenta. Možda sam se ja prevario.”

Poslednje rečenice ovog referata navode na pitanje da li je u tim teškim posleratnim godinama Božidar Kovačević i mogao da napiše drugačiji referat nego negativan. I koliko su ovaj referat diktirali strah i novi ukus. Nesporno je da je Kovačević o Kašaninovim zbirkama pisao i pozitivno i negativno, ali je teško razumljivo zbog čega je sve pozitivne strane ove proze odbacio i prećutao u ovom referatu. Nakon ovog negativnog referata, završenog kolebanjem i nesigurnošću, nije poznato da li je još neko, posle Božidara Kovačevića, bio zamoljen da oceni Kašaninov rukopis. U svakom slučaju, epilog je bio sledeći: treća knjiga pripovedaka Milana Kašanina, U senci slave, objavljena je tek 1961. godine, u izdanju Matice srpske.

Na kraju, sačuvan je još jedan prilog za proučavanje veza između Milana Kašanina i Božidara Kovačevića, a to nisu njihove međusobne kritike o kojima je bilo reči. Radi se o jednom neobjavljenom pismu iz 1979. godine, nastalom kada su već obojica ušli u zrele godine. Tada su političke okolnosti u tadašnjoj SFRJ već uveliko bile promenjene. Pismo se dugo čuvalo u porodici Milana Kašanina, a danas se nalazi u Matici srpskoj. ${ }^{12}$ Božidar Kovačević 14. novembra 1979. ovako piše Kašaninu:

Dragi Milane,

Od Veljka Sušića čujem da ste bili u bolnici. Uzbuđen sam jer verujem da ste nam mnogo potrebni. Vi znate koliko Vas cenim i koliko još od Vas očekujem. Ali se nadam da Vam je sad bolje i da nije ništa opasno pa Vam od srca želim da se oporavite.

Sreća je što imate dobru ženu koja čini da Vam boljka bude lakša. Ja sam svoju izgubio pre tri meseca posle pedeset i dve godine savršene sloge. Možete misliti

12 Pismo je Kašaninova ćerka, gospođa Marina Bojić, zajedno sa očevim rukopisima ustupila Matici srpskoj, u kojoj se radi na stvaranju Ličnog fonda „Milan Kašanin (18951981)". 
kako mi je! Pokušavam da se spasem radom ugledajući se na Vas koji ste poslednjih godina objavili nekoliko divnih knjiga. Uveren sam da će dobiti veliko priznanje kad prestane ovaj ludi vetar u našoj književnosti koji svete lampe duha i ukusa gasi.

Srdačno pozdravlja Vas i Vašu Gospođu Vaš stari prijatelj Božidar Kovačević (ROMS, Lični fond „Milan Kašanin (1895-1981)”, u nastajanju).

Ovo pismo je, po svoj prilici, jedino pismo Božidara Kovačevića koje je sačuvao Milan Kašanin. Da je navedeno pismo, toplo i tužno u isti mah, jedino raspoloživo svedočanstvo $\mathrm{u}$ rasvetljavanju njihovih međusobnih veza, lako bi navelo čitaoce na zaključak da su odnosi između dvojice pisaca bili srdačni, čak i prijateljski. To i ne bi morao biti nužno pogrešan zaključak, jer srdačni lični odnosi nisu garancija da su se oni i kao književni delatnici međusobno cenili i uvažavali. U svakom slučaju, sadržinski ovo pismo ne osvetljava njihov književni rad, izuzev činjenice da Kovačević veoma ceni Kašanina i da je uveren da bi za književno delo trebalo da dobije veliko priznanje. Ovako intoniran završetak pisma, bila to mala prigodna Kovačevićeva kurtoazija ili ne, mogao bi da zabašuri ono što su jedan o drugom svojevremeno pisali. Ili je sve tako i trebalo da bude. Jer neodoljivo se nameće utisak da je oštrina Kovačevićeve posleratne kritike prema radu Milana Kašanina predstavljala dokazivanje pravovernosti novom, komunističkom, režimu. Kovačevićevo prećutkivanje i opovrgavanje ranije izrečenih vlastitih pohvala teško da se može drugačije tumačiti nego kao strah i pravdanje pred nekim strašnim $\mathrm{i}$ uvek budnim cenzorskim okom. Otuda i mogućnost postojanja drugog lica njegove kritike. Posleratnog lica - prilično posutog pepelom. Međutim, vreme protiče, okolnosti se menjaju, strah nestaje - pa se mnogo toga i zaboravi. Uvereni smo da sve to u vreme kada je Kovačević pisao Kašaninu ovo pismo više nije bilo mnogo važno, jer su obojica - pod teretom vremena i godina - mladalačke sujete, kritike $\mathrm{i}$ borbe prepustili zaboravu. A mogućno je da Kašanin nikada nije saznao da je Božidar Kovačević posle Drugog svetskog rata bio autor negativne recenzije za njegovu zbirku pripovedaka. Ionako je smatrao, kako smo na početku teksta naveli, da jednog pisca ne bi trebalo ceniti po onome što o njemu pišu kritičari, jer vanliterarne činjenice često mogu da određuju piščevu sudbinu. 
Zorica P. Hadžić

\section{MILAN KAŠANIN AND BOŽIDAR KOVAČEVIĆ: TWO SIDES OF LITERARY CRITICISM}

\section{Summary}

This paper shows how much a change in political life can change the position of a writer in the eyes of literary criticism. As one example of such a phenomenon in literary life, this paper analyzes the collections of Milan Kašanin's stories and the literary criticism written about them by Božidar Kovačević - before and after the Second World War and the Communist Revolution. The text suggests a potential political influence on the passing of value judgments on Milan Kašanin's stories that the writer tried to publish shortly after the Second World War.

Key words: reception, literary critics, interwar literature, review, manuscript.

\section{IZVORI}

Kašanin, M. (1925). Orač tišine. Letopis Matice srpske, XCIX, 304, 155.

Kašanin, M. (1926). Poezija Božidara Kovačevića. Letopis Matice srpske, C, 307, 3,316 .

Kašanin, M. (1927). Još jedna antologija. Letopis Matice srpske, CI, 314, 1, 149150.

Kašanin, M. (1928). Todor Manojlović, Vatrometi i Bajka o Akteonu. Letopis Matice srpske, CII, 317, 2, 282-285.

Kovačević, B. (1926, mart). Tri knjige pripovedaka. Reč i slika, 94-97.

Kovačević, B. (5. mart 1929). „Zaljubljenici”. Pripovetke Milana Kašanina, Pravda, XXV, str. 5.

\section{LITERATURA}

Palavestra, P. (2008). Istorija srpske književne kritike: 1768-2007. Tom 1. Novi Sad: Matica srpska.

Vojinović, S. (ured.) (2018). Božidar Kovačević, Razgovori. Beograd: Srpsko bibliofilsko društvo.

Zogović, R. (1947). Na poprištu. Beograd: Kultura.

\section{RUKOPISNA GRAĐA}

Kašanin Milan, pismo Marku Maletinu, ROMS, inv. br. 10. 735. 
Kovačević Božidar, Referat o zbirci pripovedaka M. Kašanina „Braća pravoslavna", Arhiv SANU, inv. br. 13133/10.

Kovačević Božidar, pismo Milanu Kašaninu, ROMS, Lični fond „Milan Kašanin (1895-1981)", u nastajanju.

Savić Milan, pismo Pavlu Popoviću, Arhiv SANU, inv. br. 14492/152-5. 